\title{
Sports Involvement and Academic Achievement: A Study of Malaysian University Athletes
}

\author{
Chun Cheng Chuan ${ }^{1}$, Aminuddin Yusof ${ }^{2} \&$ Parilah Mohd Shah ${ }^{3}$ \\ ${ }^{1}$ Faculty of Educational Studies, Universiti Putra Malaysia, Malaysia \\ ${ }^{2}$ Sports Academy, Universiti Putra Malaysia, Malaysia \\ ${ }^{3}$ Faculty of Education, Universiti Kebangsaan Malaysia, Malaysia \\ Correspondence: Aminuddin Yusof, Sports Academy, Universiti Putra Malaysia, UPM Serdang 43400, Selangor, \\ Malaysia. E-mail: draminuddin@hotmail.com
}

Received: August 31, 2012 Accepted: December 3, 2012 Online Published: December 16, 2012

doi:10.5539/ies.v6n2p12 URL: http://dx.doi.org/10.5539/ies.v6n2p12

\begin{abstract}
Factors that influence the academic achievement of Malaysian university athletes were investigated using 156 field hockey players from several universities. The relationship between team subculture, parental influence, the learning environment, support systems, financial aid, training factors, academic assistance, socialization, and stress level and academic achievements of student athletes were examined using the Team Socialization Scale (Allen, 1997). There was a significant positive relationship between the learning environment and academic achievements of university athletes but a negative relationship was found between support system and academic achievements. Implications and suggestions on how to improve the academic achievement of athletes in Malaysian universities were discussed in the study.
\end{abstract}

Keywords: academic achievement, student athletes, team subculture

\section{Introduction}

Most universities aimed to produce students with good academic performance but the competitive nature of intercollegiate sports has resulted in an 'anti-intellectual' subculture (Adler \& Adler, 1985), lower academic achievement among students athletes (Allen, 1997) and also over dependency on personal support from other people for better achievement in both academic and social environment (Sack, 1988). Adler \& Adler (1985) suggest many university athletes are not ready and not interested in academic. They enrolled in a university or college to develop their career in sports. They obtained lower 'CGPA', have higher dropout rates and lower chances of completing their college education. The authors conclude that the involvement of students in sports had brought about negative influences which impacted their academic performance. According to Allen, (1997), team subculture was one of the factors that influenced the academic achievement of university athletes, apart from factors such as the behaviour of parents and academic faculty members. Allen (1997) also suggests the sub culture of a team is influenced by the behaviour of the coach and team mates and this has an effect on academic achievement throughout their university education, university athletes will be exposed to various cultures and lifestyles in the campus that could affect their academic achievements. Their culture will develop as they socialize with their peers, coaches, lecturers, university staff and faculty members, as well as academic counsellors and with others in the university community from their first year until they graduate from the university.

\subsection{Academic Subculture of Student Athletes}

One of the components in the university athletes' culture is the influence which they receive indirectly from the coach and team mates (Allen, 1997). According to Allen's research, university athletes are more likely to be influence by the behaviour of their coach and team mates. For example a male student athlete has the perception is lower academic achievement is acceptable and will still be allowed to play in the team as it is acceptable by the coach. The act of giving permission to these students to represent the team despite their non-satisfactory grade, send a signal to these students from the coach that academic achievement is not important and not a concern for them to continue playing for the team. However, female university athletes have different influence from their coach. The coach of the female team has created an environment that stresses on the importance of 
academic achievement among female university athletes. Specifically, female university athletes receive positive influence from their coaches in both their sports and academic achievements. The team agrees on reasonable academic achievements and this creates a positive team subculture among the female university athletes which leads to a positive influence on all team members' academic achievement. Team members also display a more 'pro academic' behaviour which contributes to their good academic achievements.

From the influence team mates perspectives, the male university athletes are said to have a culture of not practising the importance of academic achievement. Thus the behaviour displayed by the team members are negative on the academic achievement as to class attendance, spend more time in sports, focusing on becoming a professional athlete and others. (Allen, 1997). University athletes who are often exposed and practising non-academic behaviour unlike their team mates will influence their team mates also to have the same behaviour as them, that is one of non-academic, and vice versa.

\subsection{Problem Statement}

The effort to professionalize sports among university athletes in Malaysia has given rise to the question of whether Malaysian university athletes can achieve similar academic standings as other university students. Most research has found that university athletes obtain lower grades compared to non-athletes (Sack, 1987-88; Adler \& Adler, 1985). However, there are other researchers (Henschen \& Fry, 1884; Shapiro, 1984) who have obtained reverse findings, showing that university athletes achieved better mean grades compared to non-athletes, while the third group of researchers (Hanks \& Eckland, 1976; Stuart, 1985) found no difference in the mean grade among university athletes and non-athletes. The differences in the earlier findings need to be further researched to analyse the issues of academic achievement of university athletes. This research is conducted to determine the relationship between team subculture and the academic achievement of university athletes in Malaysia.

\subsection{Research Questions}

The research will attempt to answer the following questions;

1) What is the relationship between the coach's influence and the academic achievement of university athletes?

2) What is the relationship between team mates' influence and the academic achievement of university athletes?

3) What is the relationship between parental support and the academic achievement of university athletes?

4) What is the relationship between the learning environment and the academic achievement of university athletes?

5) What is the relationship between financial aid and the academic achievement of university athletes?

6) What is the relationship between training and the academic achievement of university athletes?

7) What is the relationship between academic assistance and the academic achievement of university athletes?

8) What is the relationship between support systems and the academic achievement of university athletes?

9) What is the relationship between socialization factors and the academic achievement of university athletes?

10) What is the relationship between stress level and the academic achievement of university athletes?

\section{Methodology}

\subsection{Subjects}

Using convenience sampling, respondents were chosen from among university athletes from five public universities in the Klang Valley who are on the hockey team in the hockey league of public universities (MASUM). The sample consists of 156 university athletes from Universiti Malaya (UM), Universiti Putra Malaysia (UPM), Universiti Kebangsaan Malaysia (UKM), Universiti Teknologi Mara (UiTM) and Universiti Islam Antarabangsa Malaysia (UIAM). The sample comprises students who are pursuing their studies and who had represented their universities in hockey competitions. 
Table 1. Subjects of the study

\begin{tabular}{lll}
\hline University & Male & Female \\
\hline Universiti Putra Malaysia (UPM) & 24 & 20 \\
Universiti Malaya (UM) & 25 & 18 \\
Universiti Kebangsaan Malaysia (UKM) & 16 & - \\
Universiti Islam Antarabangsa (UIAM) & 20 & 15 \\
Universiti Teknologi Mara (UiTM) & 18 & - \\
Total & 103 & 53 \\
\hline
\end{tabular}

\subsection{Research Instrument}

The first part of the questionnaire is about the influence of the subculture on the academic achievement of university athletes. The questionnaire was built by Allen (1997) and has 11 items with a 6-point Likert Scale to measure socialization among the university athletes from an academic perspective and their perception of the dominant academic attitudes that exist in the team subculture. Parental support and the academic achievement of university athletes have 4 items with a 6-point Likert Scale. The items used are based on Adler \& Adler (1986) and Meyer (1990) which they used in their research on socialization from an academic perspective among university athletes. The reliability of the questionnaire using Cronbach's Alpha is 0.77 for the influence of the coach and 0.76 for the influence of team mates (Allen, 1997). In this research, there are seven other factors that are considered: the learning environment (6 items), financial aid (6 items), training (7 items), academic assistance (7 items), support systems (4 items), socialization (6 items) and stress level (6 items). Upon the examination of the questionnaire by experts in sports management, these items were included in the questionnaire to measure their relationship with academic achievement among student athletes. The second part of the questionnaire is to analyse university athletes' involvement in academic and faculty activities. Astin (1993) said that involvement in academic activities include: 1) Allocation of time to attend class or lab work; 2) time to study and do homework; 3 ) time to use personal computers. Finally the third part of the questionnaire collected demographic information of the respondents such as age, gender, ethnic group, year of study and academic information such as academic results, mean grade GPA and CGPA on majors and information on sports such as competition level, the role in team (main player or reserve) and sponsorship status.

\subsection{Procedure}

Upon the approval of the Malaysian Ministry of Higher Education, the researchers applied for permission to conduct the research from the Director of Sports Center, Head of Unit, Faculty and the University Students Affairs Department. Then the researchers prepared a set of questionnaires and made appointments with the sports officer or the coach in the respective universities. After the interview, the researchers themselves distributed the questionnaires to the respondents with the help of one student. This was to prevent respondents from feeling intimidated and to avoid having them evaluate their coach in his or her presence, thereby ensuring the validity and reliability of the research findings. Before the respondents answered the questionnaire, the researchers gave a short briefing to explain the purpose of the study and how to answer the questionnaire. It was stressed that all information obtained would be confidential and used only for research purposes. After students had completed the questionnaire, the researcher and his partner collected the questionnaire.

\section{Results}

From 156 respondents, 103 or $66 \%$ of respondents are male and 53 or $34 \%$ are female. Fifty-four respondents $(34.6 \%)$ are in year 1 of their university studies, 37 respondents $(23.7 \%)$ are in year 2, 35 respondents (22.4\%) are in year 3, and 30 respondents (19.2\%) are in year 4. From these figures, it is clear that most of the university athletes in the study were in year 1 . At least 146 or $93.6 \%$ of the respondents are Malays, 2 respondents (1.3\%) are Chinese, 4 respondents (2.6\%) are Indians and the remaining 4 respondents $(2.6 \%)$ are of other races. 
Table 2. Respondents' Demographic Data

\begin{tabular}{lcc}
\hline Demographic Factor & $\mathrm{N}$ & Percentage (\%) \\
\hline Gender & 103 & 66.0 \\
Male & 53 & 34.0 \\
Female & & \\
Year of Studies & 54 & 34.6 \\
Year 1 & 37 & 23.7 \\
Year 2 & 35 & 22.4 \\
Year 3 & 30 & 19.2 \\
Year 4 & & \\
& & \\
Race & 146 & 93.6 \\
Malay & 2 & 1.3 \\
Chinese & 4 & 2.6 \\
Indian & 4 & 2.6 \\
Others & & \\
Age & & \\
18 & 2 & 1.3 \\
19 & 12 & 7.7 \\
20 & 19 & 12.2 \\
21 & 28 & 17.9 \\
22 & 44 & 28.2 \\
23 & 32 & 20.5 \\
24 & 14 & 9.0 \\
25 & 5 & 3.2 \\
Level of Involvement & & \\
International & & 17.3 \\
National & 27 & 32.1 \\
University & 50 & 5.8 \\
Others & 70 &
\end{tabular}

The respondents are aged between 18 to 25 years $(M=21.78, \mathrm{SD}=1.54)$, and those aged 22 and 23 years make up the majority of students athletes who represent the universities in hockey competitions. As for the level of competition, it was found that 27 respondents $(17.3 \%)$ had represented the country before, 50 respondents (32.1\%) had represented the state, 70 respondents $(44.9 \%)$ had represented the universities and 9 respondents $(5.8 \%)$ had participated in other levels of competition.

Table 3. Factors that Influence the Academic Achievement of University Athletes

\begin{tabular}{lcl}
\hline Factors that Influence Academic & Mean & Standard Deviation \\
Achievement & & \\
\hline Parents' Behaviour & 4.55 & 0.65 \\
Support Systems & 4.21 & 0.85 \\
Socialization & 4.15 & 0.65 \\
Training & 4.12 & 0.64 \\
Academic assistance & 4.10 & 0.59 \\
Team Mates' Behaviour & 3.90 & 0.67 \\
Learning Environment & 3.58 & 0.62 \\
Financial Aid & 3.53 & 0.68 \\
Coach's Behaviour & 3.51 & 0.58 \\
Stress Level & 3.19 & 0.68 \\
\hline
\end{tabular}


The findings in Table 3 show the influence of various factors on academic achievement among university athletes. The highest mean score is for parental influence at 4.55 (standard deviation $=0.65$ ). This is followed by support systems $($ mean $=4.15$, standard deviation $=0.65)$, socialization $($ mean $=4.15$, standard deviation $=$ $0.65)$, training $($ mean $=4.12$, standard deviation $=0.64)$, academic assistance $($ mean $=4.10$ standard deviation $=$ $0.59)$, team mates' behaviour(mean $=3.90$, standard deviation $=0.67)$, learning environment $($ mean $=3.58$, standard deviation $=0.62)$, financial aid $($ mean $=3.53$, standard deviation $=0.68)$, and coach's behaviour $(\operatorname{mean}=$ 3.51 , standard deviation $=0.58$ ). The lowest mean score is for stress level at 3.19 (standard deviation $=0.68$ ).

Therefore we can say that the behaviour of parents, team mates and coaches, the support system, training, academic assistance, and socialization can influence the academic achievement of university athletes. In conclusion, the influence of parents is a dominant factor that could influence the academic achievement of university athletes. However, all the other factors that have a mean score above 2.5 can also be treated as having a high likelihood of influencing the academic achievement of university athletes. Based on the data obtained, we found that the percentage of respondents that answered 'agree' is high for all the listed factors that could influence the university athletes' academic achievement.

Table 4 showed that there are two factor that have a high standard beta value, that is the support system factor ( $\beta$ $=-2.31)$ and learning environment factor $(\beta=0.181)$. Both factors have a significant relationship with the academic achievement of university athletes. In contrast the $\mathrm{F}$ ratio showed significant difference between means (Gay \& Diehl, 1996). The findings indicate that there is no significant relationship between all the factors researched and academic achievement of university athletes $(\mathrm{F}=1.261, \mathrm{p}>0.05)$.

The value of $R$ square $\left(R^{2}\right)$ that was obtained showed that a small variance in the dependent variable (GPA) is influenced by independent variables. With an $\mathrm{R}$ value at $0.080(0.08 \times 100=8.0 \%)$, only $8.0 \%$ constitute variance in the dependent variables (academic achievement) and are influenced by independent variables, which are factors that influence academic achievement of university athletes. As for the learning environment, the analysis shows that there is a significant relationship between the learning environment and academic achievement among university athletes. $(\beta=0.18, \mathrm{p}<0.05)$. The positive correlation indicates that if a student athlete studies with a non-athlete, spending time to study and having discussions on relevant academic matters, it can enhance his or her academic achievement. If the reverse happens, the academic achievement will be lower.

Table 4. Multiple Regression Analysis of All Factors that Influence the Academic Achievement of University Athletes

\begin{tabular}{|c|c|c|c|c|c|}
\hline \multirow[t]{2}{*}{ Dependent Variable } & \multirow{2}{*}{$\begin{array}{l}\text { Non Standard } \\
\text { Coefficient } \\
\text { B }\end{array}$} & \multicolumn{2}{|c|}{ Standard Coefficient } & \multirow[t]{2}{*}{$\mathrm{t}$} & \multirow[t]{2}{*}{$\mathrm{P}$} \\
\hline & & Standard Error & Beta & & \\
\hline Constant & 2.390 & & & & \\
\hline Coach's Influence & .090 & .073 & .113 & 1.242 & .216 \\
\hline Team Mates' Influence & -.028 & .064 & -.040 & -.438 & .662 \\
\hline Parents' Influence & -.014 & .064 & -.020 & -.224 & .823 \\
\hline Learning Environment & .135 & .064 & .181 & 2.101 & $.037^{*}$ \\
\hline Financial Aid & .033 & .063 & .048 & .519 & .605 \\
\hline Training & .008 & .073 & .012 & .115 & .908 \\
\hline Academic Support & .060 & .080 & .075 & .746 & .457 \\
\hline Support Systems & -.125 & .056 & -.231 & -2.217 & $.028^{*}$ \\
\hline Socialization & .008 & .068 & .010 & .111 & .911 \\
\hline Stress Level & .039 & .061 & .057 & .645 & .520 \\
\hline
\end{tabular}

Next, the results of analysis show a significant negative relationship between the support system and academic achievement among university athletes $(\beta=-0.23, \mathrm{p}<0.05)$. This is an indication of the existence of a reverse 
correlation between support systems and academic achievement among university athletes. The findings suggest even though athletes were not given a proper support system, but their academic achievement was still good. The analysis, however, did not show a significant relationship between other factors, that is the influence of the coach, team mates' behaviour, parents' behaviour, financial aid, training, academic assistance, socialization and stress level, and the academic achievement of university athletes.

\section{Discussion}

University students are the future leaders and will inherit their nations' leadership to develop their countries with their own cultural values and identity. Therefore it is hoped that the involvement in sports will not be a hurdle for these university students to have high academic achievements on par or even better than non-athletes. We cannot deny the fact that there are other factors that could influence the academic achievement of university athletes. However with research like this that looks into various factors that could influence academic achievement, it is hope that we can determine the dominant factors that influence the academic achievement of university athletes. The findings also indicate that the mean on the factor 'influence of parents' on the academic achievement among university athletes is the highest. This is followed by the mean on other factors that is: support systems, socialization, training, academic assistance, influence of team mates' behaviour, learning environment, financial aid, influence of coach's behaviour and stress level. Previous research has also shown that there are many relevant parties that play a major role in influencing the development of an individual. The findings are similar with past research done by Harter $(1978,1981)$ that stated that other individuals are significant, especially parents who have the most influence on their children's performance in academics (O'Sullivan \& Howe, 1996) and involvement in sports (White, 1996; Allen, 1997 \& Van -Yperen \& Duda, 1999). Research by Edwards (2000) and Harrison (2000) has also shown that there is a positive relationship between parental support and academic achievement of African American football players. The findings showed that if the parents stress more on academic achievement compared to sports achievement, the student athletes' class achievements will improve. These research also concluded that the individual, parents (Harter, 1981), coach (Allen, 1997; Ommundsen \& Robert, 1999) and peers (Smith, 1991) can motivate and influence an individual's involvement in sports.

The research findings also indicate that two out of ten factors studied, that is the learning environment and support system, have a significant relationship with the academic achievement of university athletes. This can be summarized into a direct significant positive relationship between the learning environment and academic achievement among university athletes. It is consistent with past research by Abdul Rahim Mohd Meerah (1995) to determine the relationship between academic achievements and outstanding involvement in sports in UiTM, Shah Alam. The research found that outstanding academic achievement among university athletes is because of the university's effective management in terms of providing a good learning environment, time table, and incentives that could motivate students.

\section{Conclusion}

The findings of this research were not consistent with past research that indicated that with the existence of good support systems for the university athlete, the academic achievement of these students will improve. However Malaysian education system is different especially from those in the western world that provide equal support systems to all students. In our country, only a handful of weak university athletes will be given extra attention because of their low academic achievement. They will be allocated counselling sessions, extra classes and tutorial sessions to help them improve their grades. University athletes with better grades do not get any form of additional support as their academic achievement leads to the belief that good support systems are not necessary for good academic achievement. In contrast, weaker students, in terms of academic achievement, will be given all the support they need such as counselling, and tutorials to help them achieve better grades.

For the other factors, the findings show that there is no significant relationship between academic achievement among university athletes and factors like influence of the coach's behaviour, influence of team mates' behaviour, parents' behaviour, financial aid, academic assistance, socialization, and stress level. Thus the findings are not consistent with past research done in other countries. The findings are in opposition with previous research that concluded that there is a significant relationship between coaches' behaviour and team mates' behaviour with academic achievement (Allen, 1997). However, the present findings that there is no significant relationships between academic achievement of university athletes and factors such the coaches' behaviour, team mates' behaviour, parents' behaviour, financial aid, academic assistance, socialization and stress level are in line with past research that concluded that there is no significant relationship between high academic achievement and the active involvement of outstanding university athletes in sports in UiTM, Shah Alam (Abdul Rahim Mohd Meerah, 1995). This research found that good academic achievement is not the result of active 
involvement in sports but rather is because the students have good time management and also because the university is effective in scheduling classes, and providing good learning systems and attractive incentives to motivate university athletes. Student's good time management is also found to be positively related with academic achievement. The ability to manage time skilfully refers to the setting of goals and priorities, using time management mechanics such as making lists and being organized in using time. This finding is consistent with Britton and Tesser (1991) who find time management skills and academic performance to be positively related.

Parental support was found to be positively related with academic achievement of student athletes. The results are consistent with the literature (Edwards, 2000; Harrison, 2000) which suggests student athletes performed better academically if their parents provide support in the form of parental involvement that required a large investment of time, such as discussing academic matters and communicating. Additionally, parental involvement such as parental style and expectations had a greater impact on student athlete's educational outcomes. Therefore, Malaysian universities should adopt strategies to enhance parental engagement in the education of Malaysian student athletes. For example, university administrators should identify the important facets of parental involvement that can enhance academic achievement of athletes, so that parents can be guided on what they should do to become more involved.

It cannot be denied that there are many factors that can influence the academic achievement of university athletes. University athletes have different roles from non- athletes as they need to fulfil two roles which are equally important: that of a university student and that of an athlete representing the university in sports. Thus, additional studies are needed to further examine academic achievement of university athletes especially on other factors apart from those researched in this study.

\section{References}

Abdul Rahim Mohd Meerah. (2001). Hubungan di antara pencapaian akademik dengan penglibatan sukan di kalangan atlit cemerlang UiTM Shah Alam. Unpublished Thesis Universiti Teknologi MARA, Malaysia.

Adler, P., \& Adler, P. (1985). From idealism to pragmatic detachment: The academic performance of college athletes. Sociology of Education, 58, 241-250. http://dx.doi.org/10.2307/2112226

Adler, P., \& Adler, P. (1990). Backboards and blackboards: College athletes and role engulfment. New York: Columbia University Press.

Allen, M. S. (1997). The academic socialization of intercollegiate athletes. Unpublished doctoral dissertation, University of Connecticut.

Ary, D., Jacobs, L. C., \& Razavieh, A. (1996). Introduction to Research in Education (5th ed.). Forth Worth, Rinehart and Winston.

Astin, A. W. (1993). What Matters in College: Four Critical Years Revisited. San Francisco: Jossey Bass Publishers.

Astin, A. W., Trevino, J. G., \& Wingard, T. L. (1991). The UCLA Campus Climate for Diversity. Los Angeles: Higher Education Research Institute, University of California.

Beamon, K., \& Bell, P. A. (2006). Academics versus athletics: An examination of the effects of background and socialization on African- American male student-athletes. The Social Science Journal, 43, 393-403. http://dx.doi.org/10.1016/j.soscij.2006.04.009

Borg, W. R., \& Gall, M. D. (1989). Educational Research: An Introduction (2nd ed.). New York: Longman.

Britton, B. K., \& Tesser, A. (1991). Effects of time management practices on college grades. Journal of Educational Psychology, 83(3), 405-410. http://dx.doi.org/10.1037/0022-0663.83.3.405

Campbell, D. T., \& Stanley, J. C. (1966). Experimental and Quasi-experimental Designs for Research. Chicago: Rand Mcnally and Company.

Carr, S., \& Weigand, D. A. (2002). The influence of significant others on the goal orientations of youngsters in physical education. Journal of Sport Behavior, 25, 19-40.

Castiglione, S. S. (1983). A comparison of college athletes' and non athletes' student development: Academic achievement, work values, and needs-press variables. Dissertation Abstracts International, 43, 3265A. (University Microfilms No. 83-05,620).

Donnelly, P. (1981). Toward a definition of sport subcultures. In M. Hart \& S. Birrell (Eds.), Sport and the Sociocultural Process (pp. 556-588). Dubudue, IA: Wm. C. Brown. 
Donnelly, P., \& Young, K (1988). The construction and confirmation of identity in sport subcultures. Sociology of Sport Journal, 5, 223-240.

Edwards, H. (2000). Crisis of black athletes on the eve of the $21^{\text {st }}$ century. Society, 37, 9-13. http://dx.doi.org/10.1007/BF02686167

Edwards, T. L. (1984). Scholarship and athletics. Journal of Health, Physical Education and recreation, 38, 75.

Feldman, K., \& Newcomb, T. (1969). The Impact of College on Students. San Francisco: Jossey Bass Publishers.

Feldman, K. A., \& Newcomb, T. M. (1994). The Impact of College on Students: With a new introduction by Kenneth A. Feldman. San Francisco: Jossey Bass Publishers.

Figler, S. K. (1987). The academic performance of collegiate athletes: Of playpens and backyards. Arena Review, 11, 35-40.

Figone, A. J. (1994). Teacher-coach role conflict: Its impact on students and student athletes. Physical Educator, $51,29-34$.

Gay, L. R., \& Diehl, P. L. (1996). Research Methods for Business and Management. Singapore: Prentice Hall, Simon and Schuster (Asia) Pte. Ltd.

Hanks, M. P., \& Eckland, B. K. (1976). Athletics and social participation in the educational attainment process. Sociology of Education, 49, 272-294. http://dx.doi.org/10.2307/2112314

Harris, D. (1981). Feminity and athleticism. In Gunther Luschen and George Sage (Eds.), Handbook of Social Science and Sport. Champaign, IL: Stripes.

Harrison, J. H. (1976). Intercollegiate football participation and academic achievement. Paper presented to the Southwestern Sociological Association, Dallas.

Harrison, K. (2000). Black athletes at the millennium. Society, 37, 35-39. http://dx.doi.org/10.1007/BF02686172

Harter, S. (1978). Effectance motivation reconsidered: Toward a developmental model. Human Development, 21, 34-64. http://dx.doi.org/10.1159/000271574

Harter, S. (1981). A new self-report scale of intrinsic versus extrinsic orientation in the classroom: Motivational and informational components. Developmental Psychologist, 17, 300-312. http://dx.doi.org/10.1037/0012-1649.17.3.300

Henschen, K., \& Fry, D. (1984). An archival study of the relationship of intercollegiate athletic participation and graduation. Sociology of Sport Journal, 1, 52-56.

Hood, A. B. (1992). The impact of athletics, part time employment, and other activities on academic achievement. Journal of College Student Development, 33, 447-453.

Hughes, R., \& Coakley, J. (1984). Mass society and the commercialization of sport. Sociology of Sport Journal, $1,57-63$.

Khoo Kay Kim. (2002, Februari). Jurulatih perlu kajian mendalam: Mengharap era baru. Arena Bolasepak, 56-57.

Korn, H. A. (1986). Psychological models of the impact of college on students. National Center for Research to Improve Postsecondary Teaching and Learning, Ann Arbor, MI.

Lance, L. M. (1987). Conceptualization of role relationships and role conflict among student athletes. Arena Review, 11, 12-18.

Lapchick, R. E. (2000). Crime and athletes: New radical stereotypes. Society, 37, 14-20. http://dx.doi.org/10.1007/BF02686168

Larson, S. W. (1973). A study of academic achievement of athletes at the University of Tennessee, Knoxville. The Sporting News, 24, 48.

Lederman, D. (1993). 43\% of male basketball players earned within 6 six years; Fact file: Graduation rates for athletes and other students who entered college in 1985-86. Chronicle of Higher Education, 39, A32-33.

Maloney, M. T., \& McCormick, R. E. (1992). An examination of the role that intercollegiate athletic participation plays in academic achievement: Athletes' feats in the classroom. The Journal of Human Resources, 555-570.

Mayer, B. B. (1990). The academic performance of college athletes. Sociology of Sport Journal, 7, 44-57. 
Miller, P. S., \& Kerr, G. (2002). The athletic, academic and social experiences of intercollegiate student-athletes. Journal of Sport Behavior, 25, 346-367.

Mohd. Majid Konting. (1990). Kaedah penyelidikan pendidikan. Kuala Lumpur: Dewan Bahasa dan Pustaka.

Neuman, L. W. (2003). Social Research Methods: Quanitative and quantitative approaches. Boston: New York.

O’ Sullivan, J., \& Howe, M. (1996). Causal attributions and reading achievement: Individual differences in low income families. Contemporary Educational Psychology, 21, 363-387.

Ommundsen, Y., \& Roberts, G. C., (1999). Effect of motivational climate profiles on motivational indices in team sport. Scandinavian Journal of Medicine and Science in Sports, 9, 389-397. http://dx.doi.org/10.1111/j.1600-0838.1999.tb00261.x

Pallant, J. (2001). SPSS Survival Manual: A step by step guide to data analysis using SPSS for Windows (version 10). Maryborough, Victoria.

Papaioannou, A. G., Ampatzoglou, G., Kalogiannis, P., \& Sagovits, A. (2007). Social agents, achievement goals, satisfaction and academic achievement in youth sport. Psychology of Sport and Exercise, 1-20.

Parson, T. (1951). The Social System. New York: Free Press.

Pascarella, E. T. (1991). Intercollegiate athletic participation and freshman year cognitive outcomes. University Park, PA: National Center on Postsecondary and Freshman Year Cognitive Outcomes.

Pascarella, E. T., \& Terenzini, P. T. (1991). How College Affects Students: Findings and insights from Twenty Years of Research. San Francisco: Jossey Bass Publishers.

Pascarella, E. T., Bohr, L., Nora, A., \& Terenzini, P. T. (1995). Intercollegiate athletic participation and freshman-year cognitive outcomes. Journal of Higher Education, 66, 299-387. http://dx.doi.org/10.2307/2943793

Pascarella, E. T., Duba, P., \& Iverson, B. (1983). A test and reconceptualization of a theoretical model of college withdrawal in a commuter institution setting. Sociology of Education, 56, 88-100. http://dx.doi.org/10.2307/2112657

Pascarella, E. T., Duba, P., \& Iverson, B. (1993). Intercollegiate athletic participation and freshman year cognitive success. University Park PA: National Center on Post Secondary Cognitive Outcomes.

Purdy, D. A., Eitzen, S., \& Hufnagel, R. (1982). Are athletes also students? The educational attainment of college athletes. Social Problems, 29, 439-448.

Reason, R. D., Terenzini, P. T., \& Domingo, R. J. (2006). First things first: Developing academic competence in the first year of college. Journal of Research in Higher Education, 47, 149-175. http://dx.doi.org/ 10.1007/s11162-005-8884-4

Runyon, R. A., Haber, A., \& Pittenger, D. J. (2000). Fundamentals of Behavioral Statistics (9th. Ed.). New York: The MacGraw-Hill Companies, Inc.

Sack, A. L. (1988). College sports and the student athlete. Journal of Sport and Social Issues, 11, 31-48.

Sack, A. L., \& Theil, R. (1985). College basketball and role conflict: A national survey. Sociology of Sport Journal, 2, 195-209.

Seadlacek, W. E., \& Adams-Gaston, J. (1992). Predicting academic success of student athlete using SAT and noncognitive variables. Journal of Counseling and Development, 70, 724-727. http://dx.doi.org/10.1002/j.1556-6676.1992.tb02155.x

Shapiro, B. J. (1984). Intercollegiate athletic participation and academic achievement: A case study of Michigan State University student athletes, 1950-1980. Sociology of Sport Journal, 1, 46-51.

Siegel, D. (1996). Higher education and the plight of the black male athlete. In Richard Lapchick (Ed.), Sport in society (pp. 19-34). Thousand Oaks, California: Sage.

Smith, A. L. (1999). Perceptions of peer relationships and physical activity participation in early adolescence. Journal of Sport \& Exercise Psychology, 21, 329-350.

Smoll, F. L., \& Smith, R. E., (1993). Educating youth sport coaches. An applied sport psychology perspective. In J. M. Williams (Ed.), Applied sport psychology, personal growth to pick performance. Palo Alto, CA: Mayfield. 
Stuart, D. L. (1985). Academic preparation and subsequent performance of intercollegiate football players. Journal of College Student Personnel, 26, 124-129.

Terenzini, P. T., \& Reason, R. D. (2005). Parsing the first year of college: A conceptual framework for studying college impact. Paper presented at the annual meeting of the Association for the study of Higher Education, Philadelpia, PA.

Terenzini, P. T., Springer, L., Pascarella, E. T., \& Nora, A. (1995). Academic and out-of-class influences on university intellectual orientations. The Review of Higher Education, 19(1), 23-44.

Van-Yperen, N. W., \& Duda, J. L. (1999). Goal orientations, beliefs about success, and performance improvement among young elite Dutch soccer players. Scandinavian Journal of Medicine and Science in Sports, 9, 358-364. http://dx.doi.org/10.1111/j.1600-0838.1999.tb00257.x

White, S. A. (1996). Goal orientation and perceptions of the motivational climate initiated by parents. Pediatric Exercise Science, 8(2), 122-129.

Yiannakis, A., McIntyre, T. D., \& Meinick, M. J. (1993). Sports Sociology: Contemporary Themes. Dubuque, Iowa: Kendall/Hunt Publishing Company. 